\title{
From Author to Adviser: Ruth Harrison and the Animal Machines Moment
}

Animal Machines was an instant bestseller. Five of the main part's eight chapters dealt with cruelty allegations. Of the remaining three chapters, one dealt with the impact of intensive agriculture on food quality, another covered agriculture's ecological impact, and one chapter assessed the state of existing legislation. ${ }^{1}$ According to Harrison, intensive animal husbandry was both ethically corrosive and endangered "the physical well-being of the human race." 2 No longer readily identifiable as agriculture, the factory-like nature of broiler agribusiness was a sign of things to come:

This then is the broiler industry, vast and struggling, a business rather than an agricultural enterprise as we think of agriculture. And the chickens, after nine to ten weeks in these dim, enclosed houses, reach their required weight of $31 / 2 \mathrm{lb}$ and are caught, crated and sent to the 'packing station.' ${ }^{3}$

At the end of their short lives, birds were inserted upside down into conveyor belts, their throats cut, their feathers plucked, and their guts eviscerated. Often birds were not stunned prior to the cutting of their throats.

\footnotetext{
${ }^{1}$ Harrison, Animal Machines. [In the following, I use quotations from the 2013 reprint of Animal Machines]; Marian Stamp Dawkins, "Why We Still Need to Read Animal Machines," Animal Machines-New Edition (Wallingford and Boston: CABI, 2013), 3.

${ }^{2}$ Ruth Harrison, Animal Machines-New Edition (Wallingford and Boston: CABI, 2013), 40 .

${ }^{3}$ Harrison, Animal Machines-New Edition, 55.
}

(C) The Author(s) 2021

C. Kirchhelle, Bearing Witness, Palgrave Studies in the History of Social Movements, https://doi.org/10.1007/978-3-030-62792-8_7 
Meanwhile, the high throughput of factory farms and slaughterhouses meant that diseased or residue-laden meat might well be reaching consumers. ${ }^{4}$ In the case of battery-farmed eggs, Harrison claimed that more and more birds were being held in confined conditions: "only 20 per cent are now on range, whilst 80 per cent have gone indoors." dimly lit and cramped conditions that were conducive to cannibalism, the supply of 'battery eggs' already outstripped demand and was of dubious quality. ${ }^{6}$ The particularly contentious practices of producing white veal meat and broiler beef were treated in two separate chapters (Chap. 6), followed by a less-detailed coverage of rabbits and pigs. ${ }^{7}$

In her conclusion, Ruth Harrison denied that 'factory farms' and cheap meat were in the public interest. According to Harrison, current agricultural research focused only on intensifying indoor systems and neglected alternatives. Meanwhile, annual subsidies of ca. $£ 340,000,000$ for an already oversaturated market clearly showed that further productivity increases made no sense. ${ }^{8}$ In the face of global population growth, it was more sensible to help areas of malnutrition 'help themselves' than to increase Western overproduction of animal protein. ${ }^{9}$ Government interventions such as subsidies should aim to shift farming's focus from quantity to quality. Citing the 1958 German food law and the 1958 US Delaney Clause on carcinogens, Harrison called on the UK government to protect consumers from dangerous chemical residues. She also urged consumers to use their purchasing power to support good husbandry practices and the production of safe food. Although it did not yet amount to a fully fledged 'positive' vision of welfare, Harrison ended Animal Machines by calling for "a new charter for animal welfare." ${ }^{10}$ Marking the point at which the book transitioned from using terms like "cruelty" to setting out a vision of humane farming with the term "welfare," six demands:

\footnotetext{
${ }^{4}$ Harrison, Animal Machines-New Edition, 59-64.

${ }^{5}$ Harrison, Animal Machines-New Edition, 65.

${ }^{6}$ Harrison, Animal Machines-New Edition, 65-84.

${ }^{7}$ Harrison, Animal Machines-New Edition, 85-109.

${ }^{8}$ Harrison, Animal Machines-New Edition, 197.

${ }^{9}$ Harrison, Animal Machines-New Edition, 198-200.

${ }^{10}$ Harrison, Animal Machines-New Edition, 202.

${ }^{11}$ Harrison, Animal Machines-New Edition, 202; this is in contrast to claims that Animal Machines did not use the term "welfare", Woods, "Cruelty to Welfare," 17.
} 
1. The abolition of battery cages for laying hens.

2. The abolition of current intensive veal production methods.

3. Legislation banning the rearing of animals on deficiency diets.

4. A ban on permanent tethering.

5. A ban on slats.

6. A ban on keeping animals in dim light or darkness. ${ }^{12}$

Fulfilling these demands would shape the next 36 years of Harrison's campaigning.

Although it is important to remember that 'factory farming' was by no means ubiquitous in Britain in 1964, Harrison's effective staging of a dystopian future of machine-like animals and industrialised suffering in the English countryside created a perfect moral storm. ${ }^{13}$ In addition to her carefully staged dystopian imaginary and well-orchestrated promotion campaign (Chap. 6), another reason for Harrison's impact was that she managed to avoid public alignment with either the establishment RSPCA or more radical groups like the Crusade Against All Cruelty to Animals. By presenting herself as an ordinary citizen, who was concerned about the health, environmental, and ethical fallouts of intensive farming, Harrison reached a large group of likeminded mainstream readers. ${ }^{14}$ The book did not mention Harrison's vegetarianism, family background, or Quakerism and instead strove to mobilise outrage with frequent references to industry practices designed to fool well-meaning consumers. ${ }^{15}$

The Observer articles in particular managed to create a period of sustained national indignation about animal welfare, health hazards, and intensive farming. One week after printing the second article, the leftleaning newspaper had received ca. 320 letters responding to Harrison's allegations. ${ }^{16}$ Many readers were outraged: Helen Simpson compared animals' suffering to nineteenth-century child labour, ${ }^{17}$ Sheila Mitchell

\footnotetext{
${ }^{12}$ Harrison, Animal Machines-New Edition, 202.

${ }^{13}$ Sayer, "Animal Machines," 482-483; Woods, "Rethinking the History of Modern Agriculture".

${ }^{14}$ Bernard E. Rollin, "Animal Machines-Prophecy and Philosophy," Animal MachinesNew Edition (Wallingford and Boston: CABI, 2013), 11.

${ }^{15}$ Harrison, Animal Machines-New Edition, 80, 139, 159, 163; the book's concept of who was responsible for puchasing choices was highly gendered. "Mothers" and "housewives" were addressed twice as frequently as the "consumer."

16 "Views on animal factories", Observer, 15.03.1964, 30.

${ }^{17}$ Helen M. Simpson, "Views on animal factories: Poles apart", Observer, 15.03.1964, 30.
} 
demanded labels for products from intensive farms ${ }^{18}$ and Barbara Willard asked fellow readers to imagine their pets incarcerated in factory farms. ${ }^{19}$ The RSPCA's Chief Secretary John Hall also praised Harrison's articles. ${ }^{20}$ Other prominent supporters were Canon Rhymes of Southwark Cathedral and the Dean of Llandaff. While the former attacked 'factory farming' and advertised Animal Machines in his sermons, ${ }^{21}$ the latter publicly compared factory farms to Nazi concentration camps, thereby reviving wartime discourse and 'othering' factory farms and animal cruelty as alien, barbaric, and unBritish (see Chap. 6). In a speech covered by the Daily Mirror and Guardian, the Dean also warned about residues of antibiotics, hormones, and other drugs in British food. ${ }^{22}$ The Dean's radical language triggered further appeals calling for an end of antibiotic abuse on unBritish "farm Belsens." ${ }^{23}$ In Parliament, Labour MP Joyce Butler launched a consumer-focused inquiry into agricultural chemicals and residues in food. ${ }^{24}$

There was also criticism of Animal Machines. Following the first two Observer articles, the NFU issued a press statement:

The statement in Rachel Carson's foreword 'Gone are the pastoral scenes in which animals wandered through green fields' is so absurd that only ten minutes in the countryside proves it untrue. ... It is in presenting some extreme and isolated examples of factory methods of production as if they were typical of British farming methods as a whole that this book is most misleading. ${ }^{25}$

According to the NFU organ British Farmer, the Observer had joined the "anti-land lobby" by publishing "two articles on intensive production which [give] a grossly distorted picture of British agriculture." 26 The

\footnotetext{
${ }^{18}$ Sheila M. Mitchell, "Views on animal factories: Label them", Observer, 15.03.1964, 30.

${ }^{19}$ Barbara Willard, "Views on animal factories: Try it on the dog", Observer, 15.03.1964, 30.

${ }^{20} \mathrm{John}$ Hall, "Views on animal factories: changing the law", Observer, 15.03.1964, 30.

21 "Society 'Needs a Common Morality", Times, 08.06.1964, 6; "Attack on factory farming”, Guardian, 08.06.1964, 3.

22 "Cruelty War by Church leader", Daily Mirror, 10.08.1964, 3; “'Intensive' farming condemned", Guardian, 10.08.1964, 3.

23 "Get rid of farm Belsen", Observer, 24.10.1965, 9.

24 "Hazard to health in food?", Guardian, 28.03.1964, 28.

${ }^{25}$ TNA MAF 293/169 NFU News Cycle 705/64/Press 37, “AAnimal Machines': NFU Comment on New Book" [released on 09.03.1964] (06.03.1964).

26 "Feather Heads", BF, 28.03.1964, 1.
} 
Observer was further accused of not printing an NFU counter-statement. ${ }^{27}$ In a sharply worded editorial, the agricultural magazine Farmers Weekly bemoaned:

Townspeople ... have been given a horrifying picture of the 'animal factories' ... They are given a chilling picture of broiler house concentration camps and packing station Ausschwitzen [sic], of pig 'sweat-boxes'; of darkened torture-chambers for calves, and of animals going blind in intensive beef lots. ${ }^{28}$

If animals were truly suffering, they would not thrive. The magazine also attempted to sunder Harrison's fusion of chemical and welfare critique:

Intensive animal production is under attack on humanitarian grounds which are often charged with more emotion than facts about its supposed evils. The use of certain farm chemicals is being questioned on a different planechiefly, on sober scientific findings about their persistency ... and possible effects on animals and humans. ${ }^{29}$

Critical voices also surfaced in the national media. Similar to the contemporary discrimination faced by Rachel Carson and other female animal activists, ${ }^{30}$ the language chosen to attack Animal Machines was designed to discredit its author on the basis of her gender. As discussed above, Harrison had skilfully constructed the image of a caring ordinary citizen to mobilise the public. Critics twisted this image into that of an overemotional 'housewife,' whose caring nature led her to anthropomorphise animals and whose claims could be downplayed as uneducated and unscientific. Care for animals was contrasted with 'level-headed' (male) scientific knowledge of animal husbandry and veterinary medicine. Writing to the Observer, Harrison's later ally, the Cambridge animal health lecturer David Sainsbury, accused Harrison of presenting a "grossly distorted picture of what is actually happening." 31 In the Daily Mail, agricultural commentator John Winter attempted to discredit Harrison by presenting her views as

\footnotetext{
27 "Feather Heads", BF, 28.03.1964, 1.

28 "Techniques in Question", $F W, 13.03 .1964,43$.

29 “Techniques in Question", $F W, 13.03 .1964,43$.

${ }^{30}$ Michael B. Smith, "'Silence, Miss Carson!' Science, Gender, and the Reception of "Silent Spring," Feminist Studies 27/3 (2001), 733-752; Cassidy, Vermin, 182-186, Gaarder, Women, 41-60;

${ }^{31}$ David Sainsbury, "Views on animal factories: distorted", Observer, 15.03.1964, 30
} 
those of a 'fanciful' female mind. Asking whether farmers were "really as cruel as this housewife says," Winter claimed that "it is time somebody sowed some fresh seeds in the fertile mind of Ruth Harrison." 32 According to Winter, Harrison's three-year research "crusade" against intensive production methods had "taught her little about farming." 33 Dismissing Harrison as a "housewife, mother, and vegetarian," Winter thought it logical that (female) city-dwellers would be "horrified" at conditions in even the best abattoirs:

Nobody who is unaccustomed to it is happy in a slaughterhouse, and the highspeed, mechanised death chambers of packing stations are repellent. This is largely because of their size, and the number of birds involved. But they are infinitely more humane, and hygienic, than the old primitive slaughter methods. ${ }^{34}$

By intensifying production, British farmers were only reacting to public demand for cheap food, which consumers now saw as their "birthright." 35 Most farmers were "kind and humane in their treatment of stock, without being sentimental." 36

However, even hostile commentators were soon forced to admit that dismissing Harrison as an overly sentimental housewife would not diffuse public outrage about 'factory farming.' Three days after printing John Winter's attack on Harrison, the Daily Mail was flooded with letters protesting the newspaper's perceived support of intensive methods. Although one letter applauded Winter's "level-headed criticism of Ruth Harrison's book," 37 Norman Barr from Sussex claimed, "I'll never have veal or chicken again if John Winter's article is the best defence against Animal Machines." ${ }^{38}$ Another letter renewed patriotic analogies with the Second World War and Nazi concentration camps:

\footnotetext{
${ }^{32}$ John Winter, "Are farmers really as cruel as this housewife says?", Daily Mail, 09.03.1964, 8 .

${ }^{33}$ Winter, "Are farmers really as cruel as this housewife says?".

${ }^{34}$ Winter, "Are farmers really as cruel as this housewife says?".

${ }^{35}$ Winter, "Are farmers really as cruel as this housewife says?".

${ }^{36}$ Winter, "Are farmers really as cruel as this housewife says?".

37 "Letters-Man, food and animals", Daily Mail, 13.03.1964, 10.

38 "Letters-Man, food and animals", Daily Mail, 13.03.1964, 10.
} 
According to John Winter those who deplore Belsen and other German concentration camps are expected to condone similar conditions for our farm animals so that we may have cheap food as a birthright—and the farmer mink for his wife. ${ }^{39}$

In an editorial comment, the Daily Mail acknowledged that a majority of readers who wrote shared Harrison's criticism of factory farm methods.

Criticism of factory farming also appeared in the agricultural media. Writing to Farmers Weekly in 1964, K.M. Ropewind challenged battery farms. Why was an industry suffering from overproduction so intent on producing ever more surpluses ${ }^{40}$ According to Mrs F. Belsham from Kent, Harrison's images of intensive methods were "enough to sicken any person with ordinary humane feelings" ${ }^{\prime 1}$ :

it would be a diplomatic move ... to try and stop some of these cruelties instead of forever dismissing as sentimental rubbish any attempt by anyone to show up to an ignorant public some of the methods by which their 'cheap food' is produced. ${ }^{42}$

Whether they supported or disagreed with them, it is fair to say that large parts of the British public were familiar with Animal Machines' core messages by the end of March 1964. Within three weeks, Harrison had achieved national fame.

Behind closed doors, the British government had been apprehensive about Animal Machines for a while. MAFF officials had received review copies of the book around one week ahead of the Observer articles. In their comments, officials warned, "there does not seem to be anything new in this book though the way the material is assembled and the publicity that it will get through the 'Observer' will undoubtedly lead to renewed pressure on us." ${ }^{43}$ According to MAFF Deputy Secretary W. C. Tame, "we cannot expect that references to the Protection of Animals Act or to the

\footnotetext{
39 “Letters-Man, food and animals", Daily Mail, 13.03.1964, 10.

${ }^{40}$ K.M. Petter Ropewind, "Battery Birds", FW, 27.03.1964, 41.

${ }^{41}$ F. Belsham, "Factory Farming”, FW, 27.03.1964, 42.

${ }^{42}$ Belsham, "Factory Farming".

${ }^{43}$ TNA MAF 293/169 Minute W.C. Tame to Mr Hutchison (28.02.1964).
} 
theory that animals do not thrive unless they are happy, will be readily accepted" 44 :

I wonder whether the time has come when we ought to consider seriouslyin spite of the obvious difficulties - the possibility of making regulations applying to animals kept under intensive conditions on farms similar, for example, to those applicable to animals in transit. In other words, a sort of Factories Act for animals! ${ }^{45}$

Another reviewer thought that while the "'natural food' line in the book may be less effective in practice than the cruelty line; the latter could really cause a stir especially bearing in mind the fact that it lends itself to pictorial treatment." 46 Two days after the publication of the first Observer article, another memo prepared MAFF officials for "the flood of questions and letters we must expect." ${ }^{47}$ MAFF had two options:

There is in fact a great deal to consider here and-unless the decision were to ride the storm - the course might in the end [be] to set up an independent committee of inquiry into the need for taking any action and the means which could be employed to take it. ${ }^{48}$

Another way of deflecting criticism might be to update existing regulations. In the case of John Dugdale's 1960 Bill on animal housing, MAFF officials had briefly considered extending the 1911 Act by granting cruelty inspectors right of entry on farms. However, the idea had been dropped as unpractical because it was thought that "rural benches" would be "particularly unwilling to convict" 49 potential delinquents. MAFF officials were also afraid of scaring off agricultural investors: "even rumours of legal standards to come" would make large poultry producers "hesitate before launching into vast enterprises because their capital costs would be raised." ${ }^{50}$ Another minute therefore advocated maintaining MAFF's unofficial philosophy of equating farm animal welfare with productivity:

${ }^{44}$ TNA MAF 293/169 Minute W.C. Tame to Mr Hutchison (28.02.1964).

${ }^{45}$ TNA MAF 293/169 Minute W.C. Tame to Mr Hutchison (28.02.1964); Woods, "From Cruelty to Welfare," 18.

${ }^{46}$ TNA MAF 260/351 Minute J.A. Barrah to Mr Hensley (25.02.1964).

${ }^{47}$ TNA MAF 293/169 Minute N.J.P. Hutchison to Mr Virgo (03.03.1964).

${ }^{48}$ TNA MAF 293/169 Minute N.J.P. Hutchison to Mr Virgo (03.03.1964).

${ }^{49}$ TNA MAF 293/169 Minute N.J.P. Hutchison to Mr Virgo (03.03.1964).

${ }^{50}$ TNA MAF 293/169 Minute G.P. Jupe to Mr McPhail (03.03.1964). 
All our livestock are bred and reared for ultimate slaughter. ... There are some to whom this concept is in itself anathema, but it is their lot. Our concern is to ensure that man does not aggravate the essential bestiality of an animal's existence — or degrade himself-by imposing in its lifetime or at its death circumstances which cause avoidable suffering. ... The health and comfort of animals are measurable both veterinarily and humanely by the simple test of how they thrive: the efficiency of their metabolism. ... To justify control of any circumstances imposed by man on animals we need evidence either that it is physically cruel or that, because its effect is to cause an animal not to thrive. ${ }^{51}$

Initially, it seemed as though MAFF would indeed attempt to "stonewall"52 Animal Machines. On March 10, a departmental meeting confirmed that the

general feeling, advanced most strongly by Animal Health Division, was that we should advise against any general enquiry: this was because the misgivings spring from an interpretation of animals' feelings which can only be a matter of individual opinion. It was recognized that some critics, like Ruth Harrison, a vegetarian [sic], have deep convictions about the use of animals for food at all. ${ }^{53}$

In a pre-written draft response to constituent enquiries, Conservative Minister of Agriculture Christopher Soames stated "that the Ministry does not accept many of [Ruth Harrison's] statements." 54 Although MAFF was taking Harrison's allegations seriously, "there is no evidence to show that these systems are generally cruel." 55 This line was in accordance with agroindustrial interests. Writing to Soames on March 17, the General Secretary of the Poultry and Egg Producers Association of Great Britain requested "that the Government's already declared policy ... that there is no evidence of cruelty, be re-affirmed in the clearest and most forthright terms." ${ }^{56}$ In his draft speech for the Annual Dinner of the National Egg

${ }^{51}$ TNA MAF 293/169 Minute E.S. Virgo to Mr Hutchison (04.03.1964).

${ }^{52}$ TNA MAF 293/169 Minute N.J.P. Hutchison to Mr Virgo (03.03.1964).

${ }^{53}$ TNA MAF 260/351 Minute E.S. Virgo to D. Hadley (12.03.1964).

${ }^{54}$ TNA MAF 293/169 Draft Letter to Alfred Weirs, Esq. Darenth, Kent.

${ }^{55}$ TNA MAF 293/169 Draft Letter to Alfred Weirs, Esq. Darenth, Kent; TNA MAF 293/169 [Handwritten] 1 $^{\text {st }}$ Draft: reply to debate on Mrs Joyce Butler's Motion 26/3, Poultry Husbandry.

${ }^{56}$ TNA MAF 293/169 T.J. Aley to Rt. Hon Christopher Soames (17.03.1964). 
Packers' Association one day later, MAFF's Parliamentary Secretary toasted the "the British Egg Industry-that go-ahead problem child of the agricultural industry." 57 Briefly touching upon Animal Machines, he agreed that developing a "truly effective stunner for poultry" was desirable. However, MAFF would "not accept ... that intensive farming methods as such [sic] involve unnecessary suffering." 58 While occasional management mistakes might occur, the same also held true for "more traditional forms of farming." ${ }^{59}$ In comparison to pre-war farming, modern methods were luxurious. One might even draw an analogy to humans:

I was just reflecting that we are all enjoying the benefits of intensive management at this very moment - warmth, ample food and drink, comfort, subdued lighting (or perhaps that will come later). Gentlemen, what more can one ask $?^{60}$

MAFF's strategy of stonewalling Animal Machines underestimated the onslaught of public and political pressure for meaningful reform. Described by Karen Sayer, BBC One aired a 30-minute broadcast on "Farming: Animal Machines," and theatre plays and meetings across the country took up Harrison's criticism of intensive agriculture. ${ }^{61}$ In parliament, Labour MPs Joyce Butler, John Rankin, and Fenner Brockway-who had supported Stephen Winsten's conscientious objection in 1916 (Chap. 2)-used Animal Machines to attack the already-struggling Conservative government under Alec Douglas-Home. ${ }^{62}$

Prominent animal protection organisations also became involved. Acknowledging Animal Machines' role in triggering its increased engagement with farm animal welfare, ${ }^{63}$ the RSPCA requested a Departmental

${ }^{57}$ TNA MAF 260/351 Draft Speech for the Parliamentary Secretary at the Annual Dinner of the National Egg Packers' Association (18.03.1964), 1.

${ }^{58}$ TNA MAF 260/351 Draft Speech for the Parliamentary Secretary at the Annual Dinner of the National Egg Packers' Association (18.03.1964), 3

${ }^{59}$ TNA MAF 260/351 Draft Speech for the Parliamentary Secretary at the Annual Dinner of the National Egg Packers' Association (18.03.1964), 3.

${ }^{60}$ TNA MAF 260/351 Draft Speech for the Parliamentary Secretary at the Annual Dinner of the National Egg Packers' Association (18.03.1964), 3.

${ }^{61}$ Sayer, "Animal Machines," 486.

${ }^{62}$ Sayer, "Animal Machines," 487; TNA MAF 293/169 PQs Intensive Rearing Methods (23.03.1964).

${ }^{63}$ RSPCA Archives, IF/25/1 RSPCA Intensive Farming 2 of 2, RSPCA Annual Report for 1964, 254. 
Committee "to inquire into the whole problem as affecting the intensive rearing and keeping of food animals in this country." ${ }^{64}$ RSPCA representatives moreover sought a reintroduction of the failed 1960 Animals (Control of Intensified Methods of Food Production) Bill and lamented that inspectors "could not prosecute with any reasonable hope of success under the existing [1911] law." ${ }^{5}$ The RSPCA Council also upgraded the prominence of farm animal welfare within the Society by resolving to set up a sub-committee on intensive methods of animal husbandry. ${ }^{66}$

Nine days after Animal Machines' publication, MAFF officials had no choice but to adapt their initial strategy. Although Minister Soames continued to publicly dispute "the facts as Mrs. Harrison sees them," ${ }^{67}$ Deputy Secretary Tame responded to RSPCA lobbying by conceding that "as long as anyone ... can start up these intensive systems without any kind of restriction on the conditions under which the animals are kept, we have no satisfactory answer to the humanitarians." 68 According to Tame, MAFF's only way to forestall "highly embarrassing recommendations" from an independent committee was to quickly "lay down statutory minimum standards for animals kept under intensive conditions." ${ }_{69}$ Coupled with powers of entry or enforcement, such "standards need not be any more exacting than what is already good commercial practice." 70 Assessing the overall public mood, Permanent Secretary Sir John Winnifrith agreed that "it is a dead cert that there will be an intensive and persistent campaign to induce the Government to take action."71 However, in Sir John's opinion,

${ }^{64}$ TNA MAF 260/351 Minute E.S. Virgo to Mr Hutchison (18.03.1964); RSPCA Archives, CM/55 1962-1966, Meeting of the Council, 19.03.1964, 4.

${ }^{65}$ TNA MAF 260/351 Minute E.S. Virgo to Mr Hutchison (18.03.1964); TNA MAF 293/169 John Hall to Mr Soames (12.03.1964).

${ }^{66}$ RSPCA Archives, CM/55, Meeting of the Council, 21.05.1964, 3; Meeting of the Council, 11.06.1964, 4; the sub-committee failed to gain influence until Ruth Harrison was elected to the RSPCA Council in 1969 and pushed for an ad hoc farm animals committee; RSPCA Archives, CM/58 Committee Minutes 1968-1970, 22.05.1969, 6; Meeting of the Council, 26.06.1969, 3.

${ }^{67}$ TNA MAF 260/351 Background Notes and Possible Supplementary Questions, Enclosed in: Minute ES Virgo to Mr Hutchison (18.03.1964).

${ }^{68}$ TNA MAF 121/267 Minute W.C. Tame to Mr Wall (19.03.1964).

${ }^{69}$ TNA MAF 121/267 Minute W.C. Tame to Mr Wall (19.03.1964).

${ }^{70}$ TNA MAF 121/267 Minute W.C. Tame to Mr Wall (19.03.1964).

${ }^{71}$ TNA MAF 121/267 Minute A.J.D. Winnifrith to Mr Evans (19.03.1964). 
critics would be appeased only by a Departmental Committee examining the "cruelty aspect" of "concrete [ sic] farming." "72

After discussing the two options between March 19 and 20, Minister Soames agreed to appoint a "Departmental Committee with terms of reference confined to the issue of cruelty involved." 73 However, when senior MAFF officials discussed this option with Minister Soames during another meeting on March 25, ${ }^{74}$ it became clear that a Departmental Committee would not be enough:

there is the public aspect to consider. We have ... to be seen to be tackling [the problem]; and it may be very desirable to demonstrate that independent minds are being brought to bear. If everything were to be done within the Department there might be suspicions that we were covering up. ${ }^{75}$

Officials thus decided to follow a classic corporatist strategy by bringing representatives from all sides on board and crafting a palatable compromise. ${ }^{76}$ It was advised to establish a Mixed Committee consisting of both MAFF and carefully chosen independent experts to "examine the conditions in which livestock are kept and managed under intensive husbandry methods and to recommend the standards that should obtain there." 77 It was, however, left unclear whether committee recommendations would be guidelines or "enforceable minima"78 requiring legislation.

Following Soames' consent to the establishment of a Mixed Committee under an independent chairman, the search for committee members began. ${ }^{79}$ Candidates for position of chairman were chosen not on the basis of their disciplinary expertise but on the basis of political experience and scientific standing. Suggestions included microbiologist Professor Ashley A. Miles of the Lister Institute; molecular biologist Professor Michael Swann of the University of Edinburgh; physiologist Sir Lindor Brown of the University of Oxford; and Lady Albemarle, who had recently chaired

\footnotetext{
${ }^{72}$ TNA MAF 121/267 Minute A.J.D. Winnifrith to Mr Evans (19.03.1964).

${ }^{73}$ TNA MAF 121/267 Minute M.D.M. Franklin to Mr Wall (20.03.1964).

${ }^{74}$ TNA MAF 121/267 Peter Pooley to Mr Franklin (25.03.1964), 1.

${ }^{75}$ TNA MAF 121/267 Minute R.G.R. Wall to Mr Franklin (24.03.1964), 1.

${ }^{76}$ Cox, Lowe, and Winter, "From State Direction to Self-Regulation," 475-490.

${ }^{77}$ TNA MAF 121/267 Minute R.G.R. Wall to Mr Franklin (24.03.1964), 2.

${ }^{78}$ TNA MAF 121/267 Minute R.G.R. Wall to Mr Franklin (24.03.1964), 2.

${ }^{79}$ TNA MAF 121/267 Peter Pooley to Mr Franklin (25.03.1964), 1.
} 
a committee on youth and development in the community. ${ }^{80}$ In the meantime, MAFF's "Parliamentary Secretaries should focus the attention of the Houses on the problem of standards, and shoot down the suggestions which we are not willing to investigate." $" 81$

Negotiations about the committee's size and membership were difficult. After the Home Office vetoed expanding the 1911 Act's rights of entry for cruelty inspections, ${ }^{82}$ Minister Soames emerged as a driving force for the quick establishment of a committee. Having agreed to a Daily Mirror interview on "battery farming" on April 14, Soames was "anxious that, if at all possible we should forestall the Daily Mirror articles by getting out the news of the setting up of an Advisory Committee." 83 Unfortunately, the envisaged chairman cancelled shortly after the official announcement of the planned new Committee on April 20. ${ }^{84}$ Following the suggestion of Chief Scientific Adviser Sir Solly Zuckerman, MAFF approached medical scientist Francis William Rogers Brambell, Professor of Zoology at Bangor in Wales. ${ }^{85}$ Following Brambell's acceptance of chairmanship in mid-May, the other committee members were appointed by May 29, $1964 .{ }^{86}$

The resulting Technical Committee to Enquire into the Welfare of Animals Kept Under Intensive Livestock Husbandry Systems started work in July $1964 .{ }^{87}$ At first glance, the dominance of MAFF-selected specialists did not promise radical reform. Amongst the minority of "enlightened laymen" $" 88$ was radio and television personality Lady Isobel Barnett, whose main virtues according to Permanent Secretary Winnifrith were that "many millions" knew her and "that she is most unlikely to be cranky." 89

${ }^{80}$ TNA MAF 121/267 Peter Pooley to Mr Franklin (25.03.1964), 1; TNA MAF 121/267 Minute R.G.R. Wall to Mr Franklin (24.03.1964), 2; TNA MAF 121/267 P. HumphreysDavies (07.04.1964).

${ }^{81}$ TNA MAF 121/267 Peter Pooley to Mr Franklin (25.03.1964), 2.

${ }^{82}$ TNA MAF $121 / 267$ J.C. Green to N.J.P. Hutchison (14.04.1964).

${ }^{83}$ TNA MAF 121/267 Minute Peter Pooley to Mr Wall (14.04.1964).

84 "House of Commons", Times, 12.05.1964, 16.

${ }^{85}$ TNA MAF 121/267 Peter Pooley to Mr Wall (22.04.1964); A.J.D. Winnifrith to $\mathrm{Mr}$ Wall (29.04.1964).

${ }^{86}$ TNA MAF $121 / 267$ W.C. Tame to Mr Cannel (13.05.1964); C.R. Cann to Mr Wall (29.05.1964).

${ }^{87}$ TNA MAF 121/267 C.R. Cann to Mr Wall (29.05.1964); TNA MAF 121/268 Committee on Intensive Husbandry Systems, Minutes of First Meeting (16.07.1964).

${ }^{88}$ MAF 121/267 R.G.R. Wall to Mr Virgo (26.05.1964).

${ }^{89}$ TNA MAF 121/267 A.J.D. Winnifrith to Parliamentary Secretary (10.06.1964), 2. 
Ruth Harrison was not part of the committee..$^{90}$ Despite the inclusion of the term "welfare" in its official name, ${ }^{91}$ Brambell Committee members referred to themselves as the "Committee of Enquiry into Intensive Livestock Husbandry Systems." $" 92$

For Ruth Harrison, the fact that MAFF had been forced to announce an independent committee within little over a month after the publication of Animal Machines was a major victory. ${ }^{93}$ Both the timing and promotion of the publication of Animal Machines had been perfect. However, its author now faced the decision between whether to retire from campaigning or to continue. Ruth Harrison chose the latter course.

The weeks and months following Animal Machines' publication had been a veritable crash course in public relations. During a four-hour rally at Trafalgar Square, which had been organised by the closely affiliated Animal Machines Action Group and co-financed by the RSPCA, Ruth Harrison spoke to 200 people, who had just delivered a petition with 250,000 signatures to end 'factory farms' to MAFF. ${ }^{94}$ On May 12, Ruth Harrison met four MPs to discuss 'factory farming' in the House of Commons. ${ }^{95}$

She also gained significant media experience. On March 11 - two days after the publication of Animal Machines — she appeared as a guest on the BBC's radio programme On Your Farm. The show was presented by farmer Bryan Platt, who had also invited Dr John Williams, director of the Animal Feeds Division of Ful-O-Pep Feeds, to discuss Animal Machines. ${ }^{96}$ From the beginning, both Platt and Williams attempted to downplay Harrison's allegations. Using her first name, Williams in particular tried to portray Harrison as an idealistic, yet overly emotional housewife, whose amateur research did not bear up to 'hard' scientific scrutiny:

\footnotetext{
${ }^{90}$ This is in contrast to claims by Donald M. Broom, "Ruth Harrison's Later Writings and Animal Welfare Work," Animal Machines-New Edition (Wallingford and Boston CABI, 2013), 21.

${ }^{91}$ Woods, "Cruelty to Welfare," 18.

92 TNA MAF $121 / 268$.

${ }^{93}$ A.H. Sykes, "The fatted fowl”, Guardian, 11.08.1964, 6.

${ }^{94}$ Sayer, "Animal Machines," 486; "Factory farms protest", Observer, 25.04.1965, 4; RSPCA Archives, CM 55 1962-1966, Meeting of the Council, 15.04.1965, 3.

95 "MPs see author about factory farming", Daily Mail (12.05.1964), 12; John Winter, "Farm Mail", Daily Mail (13.05.1964), 16.

${ }^{96}$ TNA MAF 260/351 Transcript from a Telediphone Recording from Talks/ General Division-Sound: On Your Farm (12:30; 11.03.1964).
} 
I would like, Ruth, right at the outset to say that I don't wish to make a point to attack you. ... But I'm sure also that you're-in putting the thoughts which you have on paper-you are extremely motivated by the highest ideals and ... indeed haven't tried to write something which is a piece of sensationalism. ... Your conclusions, I think, are somewhat illogical in that they are surrounded with an aura of sentimentality and mixed opinions. ${ }^{97}$

Following this, Harrison was allowed to present her position in onesentence statements before either Platt or Williams weighed in and demanded evidence or corrected alleged misconceptions. Platt defended the equation of welfare with animal thrift before remembering that he was supposed to be a neutral host: "I'm sorry, I hope we're not being unfair to you here at all. I am very much involved as a farmer and it's difficult to be impartial as a chairman at the same time." ${ }^{98}$ Following this, the discussion shifted to the stunning of animals and the safety of intensively farmed food. Williams referred to lack of evidence, isolated problems, and sentimental urban anthropomorphism to counter Harrison. Only in the case of antibiotics did he admit that "there has been wide abuse. ... No-one would disagree with this I think. You can say that this is a majority practice, oddly enough, as opposed to a minority. I personally [am] completely opposed to the ... the widespread use." 99

The experience of being treated in a condescending manner and seeing her allegations trivialised was not unique to On Your Farm. In 1975, Ruth Harrison remembered the radio debate and others like it during an interview published in The Vegetarian and Observer Colour Magazine. ${ }^{100}$ She was particularly annoyed by a debate with an official of the British Broiler Association:

I was tremendously unsophisticated and made my main points in what was supposed to be a pre-broadcast run through. The PR man took them down, and fed through the answers to his boss. The producer said there was no

${ }^{97}$ TNA MAF 260/351 Transcript from a Telephone Recording from Talks/ General Division-Sound: On Your Farm (12:30; 11.03.1964), 7.

${ }^{98}$ TNA MAF 260/351 Transcript from a Telephone Recording from Talks/ General Division-Sound: On Your Farm (12:30; 11.03 .1964$), 9$.

${ }^{99}$ TNA MAF 260/351 Transcript from a Telephone Recording from Talks/ General Division-Sound: On Your Farm (12:30; 11.03.1964), 12.

${ }^{100}$ Kendall, "Ruth and the Ruthless"; the interview also appeared in the Observer Colour Magazine. 
time for my opponent's main points to be put. When it went over the air they represented me as an emotional housewife, not backed up with facts. I've learnt a lot through bitter experience. ${ }^{101}$

Ruth Harrison was also invited to give evidence to the Brambell Committee. Accompanied by her husband, she appeared in front of the committee on November 20, 1964. ${ }^{102}$ By this time, committee members had already toured several intensive production facilities and assessed the debeaking of birds, high humidity houses for pigs, floor feeding, and slatted floors. ${ }^{103}$ Most importantly, they had heard a paper on animal welfare and affective states given by committee member and Harrison acquaintance William Homan Thorpe, which discussed the "sophisticated social life" 104 of all animals held under intensive positions. Building on the growing body of ethological research on animal cognition (Chap. 4), Thorpe thought it wrong to limit farm animal welfare considerations to the absence of physical pain and lack of productivity: "Animals were more intelligent and their behaviour patterns more complex than often appeared when they were kept under domesticated conditions." 105 As a consequence, animals' welfare could also be impacted by psychological stress. Later appearing as an annexe to the official Brambell Report, Thorpe's paper specifically objected to: "conditions which lead to physical deformity and to highly abnormal nutritional physiology" and "conditions which completely suppress all or nearly all the natural, instinctive urges and behaviour patterns characteristic of actions appropriate to the high degree of social organisation." 106

In her statement to the Brambell Committee, Ruth Harrison made it clear that she objected to intensive husbandry in general. She was

${ }^{101}$ Quoted according to Kendall, "Ruth and the ruthless," 2.

${ }^{102}$ TNA MAF 121/268 Committee of Enquiry into Intensive Husbandry Systems. Minutes of meeting, interview Ruth Harrison (20.11.1964), 1.

${ }^{103}$ TNA MAF 121/268 Minutes of Meeting held at Queen's Hotel, Leeds (23.09.1964), 3; TNA MAF 121/268 Minutes of Meeting held at "Great Danes" Inn, Hollingbourne (30.09.1964); TNA MAF 121/268 Minutes of Meeting held George Hotel, Nottingham (22.10.1964).

${ }^{104}$ TNA MAF 121/268 Minutes of Meeting held George Hotel, Nottingham (22.10.1964), 2 .

${ }^{105}$ TNA MAF 121/268 Minutes of Meeting held George Hotel, Nottingham (22.10.1964), 2 .

${ }^{106}$ Report of the Technical Committee to Enquire into the Welfare of Animals kept under Intensive Livestock Systems (London: HMSO, 1965), 79. 
particularly concerned about "any system of husbandry which she believed to have gone so far in intensivism as to make it impossible to maintain the health of the stock without resorting to the heavy use of drugs..."107 Harrison noted that "the traditional farmer might cause suffering through ignorance or inefficiency, but this was different from using sophisticated techniques which resulted in misery for animals." 108 In particular, Harrison objected to intensive veal crate and barley beef production systems, fully slatted sties, debeaking, dim lighting, battery cages, sweat houses, and restricting freedom of movement. However, in an important sign of things to come, "Mrs. Harrison's objections of principle were tempered with an appreciation of economic necessities." 109 She did not oppose slatted floors in dunging areas, more space for poultry within existing systems, or floor feeding for pigs. To promote good welfare, Harrison advocated amending the 1911 Act to allow enforcement "by any member of the public rather than by regulations enforced by the [MAFF]."110 RSPCA inspectors should be allowed to access "farms and other premises without resorting to the police." 111 Most importantly, further refinements to existing systems should have to comply with legally defined welfare standards guaranteeing "freedom of movement, proper diet, adequate lighting and health." 112

This appreciation of economic and political necessities was also evident in the Ruth Harrison Advisory Group's submission to the Brambell Committee. Instead of following more radical calls for a complete ban on 'factory farming,' the group advocated mandatory training and

${ }^{107}$ TNA MAF 121/268 Committee of Enquiry into Intensive Husbandry Systems. Minutes of meeting, interview Ruth Harrison (20.11.1964), 1.

${ }^{108}$ TNA MAF 121/268 Committee of Enquiry into Intensive Husbandry Systems. Minutes of meeting, interview Ruth Harrison (20.11.1964), 1.

${ }^{109}$ TNA MAF 121/268 Committee of Enquiry into Intensive Husbandry Systems. Minutes of meeting, interview Ruth Harrison (20.11.1964), 2.

${ }^{110}$ Ruth Harrison, "Letter to the Editor viz. Factory farming is here to stay", Guardian, 02.01.1965, 3; Harrison's positions in front of the Brambell Committee were nearly identical to those expressed by the RSPCA during a further session on the same day; TNA MAF 121/268 Committee of Enquiry into Intensive Husbandry Systems. Minutes of meeting, interview RSPCA (20.11.1964).

${ }^{111}$ TNA MAF 121/268 Committee of Enquiry into Intensive Husbandry Systems. Minutes of meeting, interview Ruth Harrison (20.11.1964), 3.

${ }^{112}$ TNA MAF 121/268 Committee of Enquiry into Intensive Husbandry Systems. Minutes of meeting, interview Ruth Harrison (20.11.1964), 3. 
examinations for "all staff responsible for farm birds and beasts," licences reflecting a fixed ratio of livestock to acreage, statutory standards of animal treatment, and required access to open ground for all stock of appropriate age. Further suggestions were the establishment of a welfare research centre, restricting antibiotics to therapeutic uses, establishing a code of nutritional practice, and restricting non-compliant meat imports. ${ }^{114}$

Aware that it would be futile to challenge intensive animal husbandry's very existence, Harrison and her close allies adopted a twofold strategy of pushing for gradualist statutory reforms in what Angela Cassidy has termed the "backstage" 115 of official circles while continuing to promote in public a wholesale consumer revolt against intensive farming. As a 1965 letter to the Guardian makes clear, Ruth Harrison ultimately trusted wellinformed consumers more than official standards to generate meaningful welfare improvements:

If the shopper is educated as to what her [sic] choice means, then she can discriminate. If we identify and reject the 'factory produced' product, whether from at home or abroad, then we can influence the use of these methods. ... What we can hope, with Rachel Carson, is for 'a consumers' revolt of such proportions' as will reject these inhumane methods, and count the cost in the true, humane sense. ${ }^{116}$

Over the next three decades, Harrison would relentlessly pursue this dual strategy of pushing hard for any possible improvement within the existing system of intensive farming while publicly opposing it in principle. As the author of Animal Machines, she was able to present herself as a useful intermediary, who could develop compromise policies with officials and moderate organisations like the RSPCA yet also had the ear of more radical activists. Maintaining this outsider status and continuously blurring the 'front' - and 'backstage' of politics exposed her to criticism from both sides. According to Harrison, "you're going to offend people whatever

113 “Charter suggested for farm animals' condition", Guardian, 25.11.1965, 13.

${ }^{114}$ TNA MAF 121/268 Committee of Enquiry into Intensive Husbandry Systems. Minutes of meeting, interview Ruth Harrison (20.11.1964), 2; for parallel debates on antibiotic restrictions see Kirchhelle, Pyrrhic Progress, Chapter 7.

${ }^{115}$ Cassidy, Vermin, 205.

${ }^{116}$ Ruth Harrison, "Letter to the Editor viz. Factory farming is here to stay", Guardian, $02.01 .1965,8$. 
you do ... You have almost to be a lone fighter." 117 Without firm allies in either camp, Harrison's main source of moral and public authority continued to be Animal Machines. However, given the rapid influx of new voices into the field of animal welfare, even this strong source of public authority was not limitless.

Inspired by the success of Animal Machines, other authors began to plough the field of animal welfare. In 1965, full-time writer Elspeth Huxley published Brave New Victuals. Drawing on her family connections and previous writing on wildlife conservation, ${ }^{118}$ Huxley aimed for a balanced account of intensive farming somewhere between the "land of crackpots, cranks and the lunatic fringe" and "scientific fact." she did not reference it, Huxley tackled most of Animal Machines' core themes: intensive agriculture, environmentalism, veal production, battery eggs, broiler hens, and sweat boxes for pigs. However, unlike Harrison, Huxley did not pass judgement. Describing the tens of thousands of battery hens held at Eastwood farms, she asked: "Is all this cruel? Certainly it is "unnatural'. But so are all forms of farming." ${ }^{20}$ In the case of Northern Irish pig sweat boxes, she could not find any cruelty beyond that of other intensive methods. ${ }^{121}$ Regarding veal calves, her findings were also noncommittal. While early uses of Dutch systems had resulted in excess mortality, modifications like slatted crates and dim lighting had solved many problems:

A calf penned into a narrow crate is no worse off, better off in most cases, than a calf tied up night and day in a dark, dirty corner of a draughty, flyinfested shed on a traditional farm (...), they are not, by reasons of their haemoglobin levels, in any discomfort, let alone pain. (...). The crated calves

${ }^{117}$ Quoted according to Kendall, "Ruth and the Ruthless," 21.

${ }^{118}$ Elspeth Huxley had already published numerous nonfiction and fiction books. Many focused on her previous life in Kenya and issues surrounding wildlife conservation. She was married to Gervas Huxley, cousin of Aldous and Julian Huxley, and maintained extensive correspondence with Julian Huxley on ethology, conservation, and environmentalism; Rice University, Julian Sorrell Huxley Papers, Correspondence Elspeth Huxley.

${ }^{119}$ Elspeth Huxley, Brave New Victuals. Are We All Being Slowly Poisoned? A Terrifying Enquiry Into The Techniques of Modern Food Production (London: Panther Books [1965] 1967), 10.

${ }^{120}$ Huxley, Brave New Victuals, 22.

${ }^{121}$ Huxley, Brave New Victuals, 45. 
I saw did not look unhappy; glossy of coat, bright of eye, well ventilated, clean, free of flies. ${ }^{122}$

Although she criticised liver problems resulting from barley beef production, Huxley emphasised that scientific judgement on most intensive systems remained out. ${ }^{123}$ Ethological research showed that higher herd densities and reduced space could trigger stress, and new rules might eventually be necessary "to catch up with our techniques." ${ }^{24}$ However, scientists might also be able to "dislodge" 125 stress genes. Leaving it to readers to decide whether intensive farming was cruel, Huxley instead devoted the majority of her book to the quantifiable health and environmental hazards of new weedkillers, pesticides, hormones, additives, and antibiotics in the food sector. ${ }^{126}$ According to Huxley, contrasting a romanticised world of small farms with large intensive operations was a naive juxtaposition. Change was inevitable. Regardless of whether one wanted to preserve the countryside or protect animals, the realities of global population growth meant that "a lot of animals must stay indoors." 127 But which principles should guide the design of these production facilities?

The Brambell Committee published its much-anticipated report on intensive livestock husbandry shortly after Huxley's book in December 1965. The report reflected months of intensive lobbying by all involved parties. Both the NFU and the Animal Health Trust had opposed mandatory husbandry standards. ${ }^{128}$ Interested in promoting state-sponsored preventive medicine, ${ }^{129}$ the BVA upheld "thrift" as a moderately "accurate index of welfare" 130 but called for an advisory veterinary health

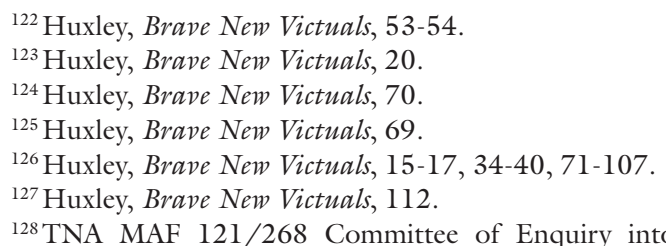

${ }^{128}$ TNA MAF 121/268 Committee of Enquiry into Intensive Husbandry Systems. Minutes of meeting, interview Animal Health Trust (03.12.1964); TNA MAF 121/268 Committee of Enquiry into Intensive Livestock Husbandry Systems. Minutes of meeting, interview NFU (18.12.1964); the Trust approved of health records oversight by veterinary inspectors.

${ }^{129}$ Abigail Woods, "Is Prevention Better Than Cure? The Rise and Fall of Veterinary Preventive Medicine, C. 1950-1980," Social History of Medicine 26/1 (2012), 113-131.

${ }^{130}$ TNA MAF 121/268 Committee of Enquiry into Intensive Husbandry Systems. Minutes of meeting, interview BVA (26.01.1965), 1 . 
service to promote and oversee good animal welfare. Although it also failed to advocate statutory regulations, the Royal College of Veterinary Surgeons (RCVS) was more explicit in criticising practices such as "deprivation of light, unnatural restraint of movement, the use of diets intended to induce a pathological state," and unnecessary mutilations. ${ }^{131}$ Animal protection and consumer organisations called for statutory reform. According to the UFAW, it was wrong to claim that "thrift was automatic proof of an acceptable level of welfare."132 The National Federation of Women's Institutes was concerned about the rise of the "non-rural business man whose concern was to extract the highest possible profit from livestock without any concern for well-being." ${ }^{133}$ Not opposed to intensive farming in principle, the Federation criticised "close confinement" and "unnecessary use of drugs or antibiotics [sic]."134 The RSPCA called for firmer regulation and subsequently launched publicity campaigns for free-range eggs and against government subsidies for new intensive broiler plants in Wales. ${ }^{135}$ The most outspoken condemnation of intensive farming came from the Humane Farming Campaign, which accused "exponents of intensivism" of "running counter to accepted Christian beliefs." 136 There were "many biblical warnings against such behaviour": "Mankind would ultimately suffer as a result of the debasement of the quality of life ... The wrath of God would be called down on our civilisation, as it was on the Egyptians." 137

${ }^{131}$ TNA MAF 121/268 Committee of Enquiry into Intensive Husbandry Systems. Minutes of meeting, interview RCVS (12.02.1965), 2.

${ }^{132}$ TNA MAF 121/268 Committee of Enquiry into Intensive Husbandry Systems. Minutes of meeting, interview UFAW (26.01.1965), 3.

${ }^{133}$ TNA MAF 121/268 Committee of Enquiry into Intensive Husbandry Systems. Minutes of meeting, interview National Federation of Women's institutes (12.02.1965), 1.

${ }^{134}$ TNA MAF 121/268 Committee of Enquiry into Intensive Husbandry Systems. Minutes of meeting, interview National Federation of Women's institutes (12.02.1965), 2.

${ }^{135}$ TNA MAF 121/268 Committee of Enquiry into Intensive Husbandry Systems. Minutes of meeting, interview RSPCA (20.11.1964); RSPCA Archives, CM/55 1962-1966, Meeting of the Council, 11.06.1964, 3-4; Meeting of the Council, 17.02.1966, 3; Meeting of the Council, 17.03.1966, 3 .

${ }^{136}$ TNA MAF 121/268 Committee of Enquiry into Intensive Husbandry Systems. Minutes of meeting, interview Humane Farming Campaign (26.01.1965), 1.

${ }^{137}$ TNA MAF 121/268 Committee of Enquiry into Intensive Husbandry Systems. Minutes of meeting, interview Humane Farming Campaign (26.01.1965), 1. 
Navigating between predictions of agricultural bankruptcy and divine wrath, the main Brambell Report recommended promoting more behavioural research on animal welfare, improving the education of stockmen, and installing a standing Advisory Committee to advise Ministers on farm animal welfare. Members of the Advisory Committee should be appointed for their own qualifications and not as representatives of particular interests. ${ }^{138}$ Although it made concrete recommendations regarding space, lighting, diets, ventilation, and flooring and also criticised practices such as debeaking and tethering, ${ }^{139}$ the Brambell Committee did not advocate amending the 1911 Act. Instead, it called for a "new and brief animal welfare act." ${ }^{140}$ Handed to MAFF on October 25 and published on December 2, 1965, ${ }^{141}$ the report's most lasting contribution was to call for an expansion of the definition of animal suffering - or negative welfarefrom physical pain and mental cruelty as defined by the 1911 Act to encompass discomfort, stress and pain: welfare was a "wide term that embraces both the physical and mental well-being of animals." ${ }^{142}$ Building on Thorpe's recommendations, the report stated that an "animal should at least have sufficient freedom of movement to be able without difficulty, to turn round, groom itself, get up, lie down and stretch its limbs." 143 What a positive state of well-being might look like beyond the absence of negative welfare factors like stress was not discussed.

In their initial assessment of the Brambell Report, MAFF officials were surprised by how cheap it would be to implement many of its recommendations. ${ }^{144}$ The major concern was how to deal with cheaper livestock imports from countries not adhering to Brambell standards: "the foreigner

${ }^{138}$ TNA MAF 121/268 Committee of Enquiry into Intensive Husbandry Systems. Minutes of meeting (13-15.07.1965), 2.

${ }^{139}$ Report of the Technical Committee to Enquire into the Welfare of Animals kept under Intensive Livestock Systems (London: HMSO, 1965), 63-65.

${ }^{140}$ TNA MAF 121/268 Committee of Enquiry into Intensive Husbandry Systems. Minutes of meeting (27.-28.07.1965), 2.

${ }^{141}$ TNA MAF 369/32 Animal Health Division II: Brambell Committee. Meeting of Officials on $18^{\text {th }}$ November. Notes for Mr Humphreys-Davies (17.11.1965), 1.

${ }^{142}$ Report of the Technical Committee to Enquire into the Welfare of Animals, 9; Woods, "Cruelty to Welfare," 19; this definition was partly inspired by the recent Littlewood Report on Experiments on Animals.

${ }^{143}$ Report of the Technical Committee to Enquire into the Welfare of Animals, 13.

${ }^{144}$ TNA MAF 369/32 Minute A.J.D. Winnifrith to Minister (24.11.1965). 
might be enabled to get a bigger share of the UK market." ${ }^{145}$ MAFF Deputy Secretary Peter Humphreys-Davies noted:

the [Brambell] Committee have struck a reasonable balance between the agriculture and food interests on the one hand and the sentimentalists on the other. The producers, for instance, have only lost out completely on white veal and the pig seat-houses. The battery system only requires to be modified and not prohibited, ... Debeaking was on the way out anyway. ... The worst of these, perhaps, is the proposal that the same standards should be applied to imports: ... The recommendation about the tethering of beef cattle (and by implication dairy cows) in winter is also clearly unacceptable as it stands. ... The cost considerations ... are to my mind far less formidable: given a reasonable transitional period, and perhaps some help in the Annual Review, the extra cost ought to be absorbed easily enough in course of time. ${ }^{146}$

Almost two years after the publication of Animal Machines, public pressure for immediate welfare reform had, however, diminished. With Britain struggling to maintain its balance-of-payments, ${ }^{147}$ MAFF officials were unwilling to allow welfare reforms to jeopardise agricultural efficiency. Meanwhile, the Home Office insisted that the 1911 Act was a sufficient safeguard for animal protection and opposed including the word "stress" 148 in a new welfare bill. Despite positive continental reactions to the Brambell Report, ${ }^{149}$ British regulators decided to either ignore or

${ }^{145}$ TNA MAF 369/32 Fatstock Policy Division, Report of the Brambell Committee (15.11.1965), 1; TNA MAF 369/32 Animal Health Division II: Brambell Committee. Meeting of Officials on $18^{\text {th }}$ November. Notes for Mr Humphreys-Davies (17.11.1965).

${ }^{146}$ TNA MAF 369/32 Minute P. Humphreys-Davies to Secretary (24.11.1965).

${ }^{147}$ Martin, The Development of Modern Agriculture, 88-91; fears of lacking efficiency vis-àvis EEC competitors were repeatedly mentioned by the NFU; TNA MAF 369/77 Farm Animal Welfare Legislative Proposals. Note of a meeting with the NFU held on 16.03.1967 (01.05.1967), 1 .

${ }^{148}$ TNA MAF 369/47 Draft Minute, Enclosed in, Minute G.O. Lace to Mr Humphreys Davies (31.08.1966)

${ }^{149}$ Bayerisches Hauptstaatsarchiv (HSTA)—MInn 87782 III-5594/2-2/66 Der BMELF an die für das Veterinärwesen zuständigen obersten Landesbehörden (11.08.1966). 
weaken many of its recommendations. Legislation to improve the education of stockmen was considered impracticable. ${ }^{150}$ In the case of the committee's space recommendations, MAFF officials contradicted earlier assessments and warned, "if implemented, Brambell must marginally, but perhaps overall imperceptibly, increase the cost of food; will raise costs or reduce output for some producers far from imperceptibly; and will check the momentum of increased efficiency." 151 According to AssistantSecretary G.O. Lace, it was impossible to "see how Ministers can decide, before consulting the trade on fairly detailed proposals, either to what extent to modify Brambell, or where to place the cost of it." ${ }^{152}$

MAFF consultations with industry and welfare interests lasted for another year and further weakened many Brambell recommendations. ${ }^{153}$ In its original comment on the Brambell Report, MAFF had already declared that it "could not impose detailed statutory standards at the present time." ${ }^{154}$ Codes of practice would be drawn up, and state veterinarians would provide advice to farmers on these voluntary codes. Like the Highway Code, non-compliance would not be an offence but could be used to establish culpability in cruelty prosecutions. ${ }^{155}$ The new welfare bill would not make sweeping reforms but would allow Ministers of Agriculture to make regulations on a case-by-case basis. A major Brambell recommendation to remain unchallenged was the establishment of a Farm Animal Welfare Advisory Committee (FAWAC). In August 1966, MAFF publicly agreed to set up an advisory committee on animal welfare. ${ }^{156}$ However, the extent of the committee's power was contested. Officials thought it best not to let FAWAC re-examine systems that had "passed the Brambell Test" and saw "perhaps some nuisance, in the Committee being statutory." 157 Following drawn-out discussions, MAFF decided to

${ }^{150}$ TNA MAF 369/47 G.O. Lace, "Note for Minister. Brambell Committee ReportPossible Courses of Action" (17.05.1966), 2.

${ }^{151}$ TNA MAF 369/47 G.O. Lace/Mr Hensley, "Brambell Report" (undated), 17; see also: 1-12.

${ }^{152}$ TNA MAF 369/47 G.O. Lace/Mr Hensley, "Brambell Report” (undated), 17.

${ }^{153}$ TNA MAF 369/77 Press Release MAFF (02.11.1967-1)

${ }^{154}$ TNA MAF 369/272 Joint Announcement by the Agricultural Departments in the United Kingdom MAFF (05.08.1966), 2.

${ }^{155}$ TNA MAF 369/272 Joint Announcement by the Agricultural Departments in the United Kingdom MAFF (05.08.1966), 2.

${ }^{156}$ TNA MAF 369/272 Joint Announcement by the Agricultural Departments in the United Kingdom MAFF (05.08.1966), 2.

${ }^{157}$ TNA MAF 369/47 G.O. Lace/Mr Hensley, "Brambell Report” (undated), 4. 
establish FAWAC as a non-statutory, standing body "to advise ... on matters pertaining to the welfare of farm animals." 158 The committee was to have eight to ten "general members," who represented different interests but were not "nominees" of "particular interests." 159 FAWAC should comprise amongst others an animal behaviourist, a geneticist, and "one or two" zoologists and "independent veterinarians." 160 It was not necessary for the chairperson to have a "particular field of knowledge" but to be "strong-minded, independent and able to manage what could be a difficult committee."161

Despite her disappointment about the abandonment of many Brambell principles, Ruth Harrison quickly recognised that FAWAC offered an opportunity to influence the future development of British welfare regulations. Starting in August 1966, she used her status as a prominent yet moderate 'outsider' with semi-expert credentials to lobby MAFF for FAWAC membership. Having met Ruth Harrison for lunch on August 18, MAFF official D. Evans informed Assistant-Secretary G.O. Lace:

\begin{abstract}
[Ruth Harrison] was very interested in the Advisory Committee, and fished for a long time for me to say something about it. In the end she asked me direct whether I thought she would be invited to be a member; I said I honestly did not know, ... I supposed she might be regarded as eligible, but from my understanding of matters there might be a good deal of opposition from trade interests and others if she were invited. She told me that she would probably serve if asked, though she was a little worried about being 'gagged.'162
\end{abstract}

According to Evans, "Mrs. Harrison was at pains to impress on me that she regards herself as a 'moderate' in the Animal Welfare Movement."163

Not all officials were enthusiastic about appointing Ruth Harrison to FAWAC. Reviewing the list of potential candidates, MAFF Deputy Secretary Peter Humphreys-Davies recommended dropping both Ruth Harrison and her co-nominee the Dean of Llandaff. ${ }^{164}$ MAFF

\footnotetext{
${ }^{158}$ TNA MAF 369/47 Minute P. Humphreys-Davies to Secretary (07.09.1966), 2. ${ }^{159}$ TNA MAF 369/47 Minute P. Humphreys-Davies to Secretary (07.09.1966), 2. ${ }^{160}$ TNA MAF 369/47 Minute P. Humphreys-Davies to Secretary (07.09.1966), 2. ${ }^{161}$ TNA MAF 369/47 Minute P. Humphreys-Davies to Secretary (07.09.1966), 2. 162 TNA MAF 369/47 Minute D. Evans to Mr Lace (19.08.1966). ${ }^{163}$ TNA MAF 369/47 Minute D. Evans to Mr Lace (19.08.1966). ${ }^{164}$ TNA MAF 369/47 Minute P. Humphreys-Davies to Mr Hensley (11.01.1967).
} 
under-secretary C.H.M. Wilcox favoured nominating former Brambell member Lady Isobel Barnett alongside Elspeth Huxley-on the basis of her 'balanced' Brave New Victuals-and excluding Ruth Harrison. However, he could "appreciate that there are no doubt strong political arguments for taking the latter." 165 By contrast, Under-Secretary of State for Scotland Lord Hughes, "when told that Mrs. Harrison was on the list, thought her better on than off." 166 This opinion was shared by G.O. Lace: "I gather that if we want anyone from outside the established societies she would indeed be the most moderate of the well-known people."167 Meanwhile, MAFF official D. Evans indirectly pushed for Ruth Harrison by casting doubt on Elspeth Huxley's commitment to animal welfare:

I think there is no doubt about her impartiality (though I am not sure that this is what is wanted in a 'welfare' member) but in my dealings with her when the Brambell Committee was sitting I gained the impression that she thought of her work on this subject simply as a professional journalist would do and had no lasting interest in it. ${ }^{168}$

All the while, Ruth Harrison continued to actively push for FAWAC membership. Phoning MAFF on September 14, 1966, "she told [Evans] she had given a lot of thought to the [Minister's proposed action on the Brambell Report] and had come to the conclusion that our proposals were much better than she originally thought." ${ }^{69}$ Again stressing her credentials as a moderate, "she said she was thinking of writing to the Minister to offer her support." ${ }^{170}$ In the course of the conversation, Evans once again "got the impression that Mrs. Harrison is very anxious to be on the Standing Committee." ${ }^{\prime 71}$ Referring to Ruth Harrison's recent statements and "varying accounts" of Lady Isobel Barnett's performance on the Brambell Committee, another MAFF minute noted, "[Harrison] has taken a balanced and objective view and I think on the whole she should be invited." ${ }^{172}$

\footnotetext{
${ }^{165}$ TNA MAF 369/47 Minute C.H.M. Wilcox to W.E. Jones (09.09.1966).

${ }^{166}$ TNA MAF 369/47 Minute W.E. Jones to C.H.M. Wilcox (13.09.1966), 1.

${ }^{167}$ TNA MAF 369/47 Minute G.O. Lace to Mr Hensley (24.08.1966).

${ }^{168}$ TNA MAF 369/47 Minute D. Evans to Mr Hensley (15.09.1966).

${ }^{169}$ TNA MAF 369/47 Minute D. Evans to Mrs Avery (15.09.1966).

${ }^{170}$ TNA MAF 369/47 Minute D. Evans to Mrs Avery (15.09.1966).

${ }^{171}$ TNA MAF 369/47 Minute D. Evans to Mrs Avery (15.09.1966).

${ }^{172}$ TNA MAF 369/47 Minute P. Humphreys-Davies to Secretary (07.09.1966), 2.
} 
Clearly designed to aid Harrison's FAWAC membership campaign, the Ruth Harrison Advisory Group submitted extremely moderate comments on MAFF's proposed animal welfare reforms in November 1966: ${ }^{173}$

The Minister's Proposals could be an excellent framework within which a solution can be found for the ultimate welfare of food animals, further, they are sufficiently flexible to allow for further change in the light of increasing knowledge and public concern. ${ }^{174}$

In contrast to strong criticism from groups like the National Campaign for the Abolition of Factory Farming, the Humane Farming Campaign, and the RSPCA, ${ }^{175}$ the Advisory Group merely called for more detailed voluntary codes for indoor and outdoor farming "after the manner of the advisory pamphlets issued by the Ministries since the last war." 176 It was hoped that the Brambell recommendations would not be interpreted as absolute standards but "as a minimum, and a point of departure." 177 Regarding welfare controls of ca. 360,000 agricultural holdings by ca. 600 veterinary surgeons and staff, the Advisory Group suggested that the Minister allow "any person or organisation, with the backing of a veterinary surgeon, to take action where this is necessary." 178 The Advisory Group's strongest criticism centred on the postponement of regulatory action until further scientific assessments had been completed:

Whilst we understand the Ministers' reluctance to involve producers in capital expenditure ..., we are apprehensive that this could become a ground for

${ }^{173}$ TNA MAF 369/75 Minute G.O. Lace to Mr Hensley (16.11.1966).

${ }^{174}$ TNA MAF 369/75 Ruth Harrison Advisory Group, “Comment on the Minister's Proposals for Legislation following on the Brambell Report" (08.11.1966), enclosed in: Minute G.O. Lace to Mr Hensley (16.11.1966), 1.

${ }_{175}$ TNA MAF 369/75 Humane Farming Campaign-Farm Animal Welfare-Proposals for Legislation; TNA MAF 369/75 Lucy Newman to MAFF (16.11.1966); TNA MAF 369/77 RSPCA to HB Fawcett (12.09.1967).

${ }^{176}$ TNA MAF 369/75 Ruth Harrison Advisory Group, “Comment on the Minister's Proposals for Legislation following on the Brambell Report” (08.11.1966), enclosed in: Minute G.O. Lace to Mr Hensley (16.11.1966), 1.

${ }^{177}$ TNA MAF 369/75 Ruth Harrison Advisory Group, "Comment on the Minister's Proposals for Legislation following on the Brambell Report" (08.11.1966), enclosed in: Minute G.O. Lace to Mr Hensley (16.11.1966), 2.

${ }^{178}$ TNA MAF 369/75 Ruth Harrison Advisory Group, "Comment on the Minister's Proposals for Legislation following on the Brambell Report" (08.11.1966), enclosed in: Minute G.O. Lace to Mr Hensley (16.11.1966), 3. 
virtually indefinite postponement of action. ... If the Ministers incorporated the Brambell Committee recommendations into the Code of Practice, making each one statutory as soon as they felt they had sufficient evidence and support to do so, and if this were backed up by strong enough powers of prosecution, ... then we would welcome their proposals as being a very real step forward in the welfare of farm animals. ${ }^{179}$

Voicing similar demands, a group of well-known activists and experts, including Ruth Harrison, William Homan Thorpe, and Soil Association founder Eve Balfour, published a letter in the Times in May 1967:

Only two steps are needed ..., first for the Minister of Agriculture to have [the Brambell] recommendations incorporated without any further modification in the proposed voluntary Code of Practice contemplated in his prospective Bill, and secondly for the Government to make time for the Bill to be passed through Parliament. ${ }^{180}$

New regulations and codes should enact basic Brambell recommendations: an animal should have freedom of movement, be able to turn round, groom itself, get up, lie down, and stretch its limbs; diets should be designed to maintain animals' full health and vigour; adequate illumination should be available for the proper and routine inspection of all animals. These recommendations "were so fundamental that one feels surprised that the necessity ever arose for them to be made."181

The letter failed to impact official decision-making. In August 1967, MAFF circulated new draft provisions for the upcoming welfare law. Little had changed. The usually moderate RSPCA criticised the ongoing absence of statutory regulations except for proposed bans on the bleeding of calves and tail-docking of cattle alongside regulations for adequate lighting and minimum iron in diets. Proposed fines remained too low to deter malpractice, and relying on voluntary codes promised to delay welfare

${ }^{179}$ TNA MAF 369/75 Ruth Harrison Advisory Group, “Comment on the Minister's Proposals for Legislation following on the Brambell Report" (08.11.1966), enclosed in: Minute G.O. Lace to Mr Hensley (16.11.1966), 3-4.

${ }^{180}$ TNA MAF $369 / 77$ "The Welfare of Farm Animals" (29 April), The Times (11.05.1967), 13A.

${ }^{181}$ TNA MAF 369/77 "The Welfare of Farm Animals" (29 April), The Times (11.05.1967), 13A. 
improvements on farms. ${ }^{182}$ However, political momentum for more ambitious reforms had ebbed. Announced in early November 1967 and passed in 1968, ${ }^{183}$ the Agriculture (Miscellaneous Provisions) Bill complemented but did not replace the 1911 Cruelty to Animals Act by making it an offence to cause "unnecessary pain and distress" to livestock. ${ }^{184}$ It also empowered MAFF to establish voluntary codes of practice and make statutory welfare regulations with regard to housing, feeding, and mutilation after consulting relevant interests. ${ }^{185}$ The Act granted official veterinarians the right to enter and inspect farms. ${ }^{186}$ However, there was no mention of mandatory space and nutritional requirements, and lighting standards, nor a concrete definition of what unnecessary pain and distress meant. ${ }^{187}$ Decisions on controversial practices like the docking of pigs' tails were referred for further consultation to the new FAWAC.

Already established in late 1967, MAFF's new expert welfare body was composed of officials, scientists, industry representatives, and welfare campaigners-including RSPCA member Irene Walsh and Ruth Harrison. ${ }^{188}$ Although the much-weakened 1968 Bill did not meet the demands of either Animal Machines or the 1965 Brambell Report, her nomination to FAWAC was a major personal success for Harrison. Previously belittled as an emotional housewife, she had skilfully used the political momentum of

${ }^{182}$ RSPCA Archives, Meeting of the Council, 23.11.1967, Attached: R.F. Seager to all members of the Council, 14.12.1967 and attached minutes of General Purposes committee, 02.11.1967 and enclosed letter: R.F. Seager to H.B. Fawcett (MAFF), 12.09. 1967.

${ }^{183}$ TNA MAF 369/77 Press Release MAFF (02.11.1967-1).

${ }^{184}$ Agriculture (Miscellaneous Provisions) Act 1968, Legislation.gov.uk; http://www.legislation.gov.uk/ukpga/1968/34 [09.01.2015].

${ }^{185}$ TNA MAF 369/90 Agriculture (Miscellaneous Provisions) Bill. Explanatory Memorandum. Part 1 Welfare Livestock.

${ }^{186}$ TNA MAF 369/90 Agriculture (Miscellaneous Provisions) Bill. Explanatory Memorandum. Part 1 Welfare Livestock; TNA MAF 369/272 Annex A-General Background, enclosed in: Storey to Mr Hann (13.03.1981), 1.

${ }^{187}$ TNA MAF 369/272 Annex A-General Background, enclosed in: Storey to Mr Hann (13.03.1981),1-3.

${ }^{188}$ TNA MAF 369/77 H.B. Fawcett to [anonymous] (18.09.1967); RSPCA Council had not been consulted about the appointment of Walsh, who had been a civil servant and served in a branch of the Secret Service during the Second World War. It subsequently tried to influence Walsh's actions and also tried to influence fellow FAWAC member Major Graham, vice-chairman of the Country Landowners' Association; RSPCA Archives, CM/57: 1966-1968; Meeting of the Council, 27.07.1968, 4; Meeting of the Council, 26.10.1967, 2-3. 
her bestseller and her public status as a charismatic outsider to gain access to the confidential 'backstage' of British advisory committees. Remarkably, Harrison had done so without tethering herself to any of the major British agricultural, consumer, or welfare organisations. By stressing her position as an independent 'moderate' within the budding welfare movement, Harrison gave MAFF officials the impression of being an 'easy' choice to generate public acceptance for FAWAC and its upcoming welfare assessments. This impression soon proved incorrect.

Open Access This chapter is licensed under the terms of the Creative Commons Attribution 4.0 International License (http://creativecommons.org/licenses/ by $/ 4.0 /$ ), which permits use, sharing, adaptation, distribution and reproduction in any medium or format, as long as you give appropriate credit to the original author(s) and the source, provide a link to the Creative Commons licence and indicate if changes were made.

The images or other third party material in this chapter are included in the chapter's Creative Commons licence, unless indicated otherwise in a credit line to the material. If material is not included in the chapter's Creative Commons licence and your intended use is not permitted by statutory regulation or exceeds the permitted use, you will need to obtain permission directly from the copyright holder. 